\title{
Are Multiple Primary Melanomas a Rare Entity?
}

\author{
Nika Franceschi ${ }^{1}\left(\mathbb{D}\right.$, Marija Buljan ${ }^{1,2}$, Mirna Šitum ${ }^{1,2}$ \\ ${ }^{1}$ Department of Dermatology and Venereology, Sestre milosrdnice University Hospital Centre, Zagreb, Croatia \\ ${ }^{2}$ School of Dental Medicine, University of Zagreb, Zagreb, Croatia
}

\begin{abstract}
:
Multiple primary melanomas are described in literature as a relatively rare, but nevertheless well known entity. The incidence varies from 0.2 to $23 \%$ worldwide. Many risk factors for the development of multiple primary melanomas have been observed, including multiple dysplastic nevi, positive family history, over 60 years of age at diagnosis of first melanoma, male sex and white race. The first primary melanoma in patients with multiple primary melanomas has the greatest tumour thickness, while subsequent melanomas are usually significantly less invasive, most probably due to strict follow-up schedules and regular self-examinations. We will report of two patients with multiple primary melanomas and follow-up methods for early detection of other primary melanomas.
\end{abstract}

KEYWORDS: melanoma, multiple primary melanoma, risk factors, dermoscopy, dysplastic nevus syndrome

\section{SAŽETAK:}

Multipli primarni melanomi se u literaturi navode kao relativno rijedak, ali dobro poznat entitet, a podaci o incidenciji variraju od 0,2 do $23 \%$ diljem svijeta. Mnogi čimbenici rizika razvoja multiplih primarnih melanoma se opisuju, uključujući pozitivna obiteljska anamneza, brojni displastični nevusi, prvi primarni melanom otkriven poslije 60. godine života, svijetla put i muški spol. Prvi je melanom u većini slučajeva najveće debljine, dok su ostali melanomi značajno manje invazivni što se povezuje s redovitim praćenjem i samopregledima. Prikazat ćemo dva pacijenta s multiplim primarnim melanomima te metode praćenja tih bolesnika za rano otkrivanje novih primarnih melanoma.

KLJUČNE RIJEČI: melanom, multipli primarni melanomi, čimbenici riziki, dermatoskopija, sindrom displastičnih nevusa

OPEN ACCESS

Correspondence: Nika Franceschi MD

nika.franceschi@gmail.com orcid.org/0000-0002-7426-7547

This article was submitted to RAD CASA - Medical Sciences as the case report

Conflict of Interest Statement: The authors declare that the research was conducted in the absence of any commercial or financial relationships that could be construed as a potential conflict of interest.

Received: 10 June 2019 Accepted: 24 June 2019 Published: 22 July 2019

Citation:

Franceschi N, Buljan M and Situm M. Are multiple primary melanomas a rare entity? RAD CASA - Medical Sciences. $537=46-47$ (2019): 44-47 DOI: $10.21857 / y p n 40 c 8 j w 9$

Copyright (C) 2019 Franceschi, Buljan and Situm.This is an open-access article distributed under the terms of the Creative Commons Attribution License (CC BY). The use, distribution or reproduction in other forums is permitted, provided the original author(s) and the copyright owners(s) are credited and that the original publication in this journal is cited, in accordance whit accepted adacemic practice. No use, distribution or reproduction is permitted which does not comply with these terms. 


\section{INTRODUCTION}

Multiple primary melanomas are described in the literature as a relatively rare, however well-known entity. Incidence varies from 0.2 to $8.6 \%$ in Europe, while in populations with high melanoma incidence, such as Queensland, Australia, multiple primary melanoma incidence is as high as $23 \%{ }^{1,2}$. Multiple primary melanomas were first described in the literature by Pack and colleagues in $1952^{3}$, and the highest number of primary melanomas observed in one patient is $48^{4}$. Patients with a personal history of melanoma have a 9 to 25 times higher risk of developing another melanoma than the risk of developing melanoma in the general population ${ }^{5}$. People with multiple dysplastic nevi and/or positive family history have the highest risk of developing multiple primary melanomas ${ }^{6-9}$. Additionally, more than 60 years of age at diagnosis of first melanoma, male sex and white race have also been observed as risk factors ${ }^{10}$. As much as 18 to $36 \%$ of multiple primary melanoma patients have a positive family history for melanoma, while 38 to $46 \%$ of patients with multiple primary melanomas have dysplastic nevi ${ }^{6,11,12}$.

The risk of developing a second primary melanoma is greatest within the first year, however, remains increased for more than 20 years after the first primary melanoma diagnosis $7,13-15$. In patients with multiple primary melanoma the first melanoma has the greatest tumor thickness, while subsequent melanomas are usually significantly less invasive. Ferrone and colleagues reported in situ melanoma accounting for $21 \%$ of first primary melanomas, $50 \%$ of second, $55 \%$ of third and $70 \%$ of fourth primary melanomas, confirming the observation that in situ melanoma diagnosis is more frequent in subsequent melanomas 5,7,10,16-19. Lower incidence of vertical growth phase and nodular histotype have also been reported in invasive subsequent melanomas ${ }^{7,16}$. These observations are most probably associated with strict follow-up schedules and regular self-examinations, and therefore earlier detection of new melanomas. Less aggressive tumor biology and development of sinecomitant immunity have also been previously suggested ${ }^{7,20}$. However, unlike earlier research results, several recent studies have shown that patients with multiple primary melanomas have a poorer survival compared to patients with a single primary melanoma ${ }^{10,21,22}$.

\section{CASE REPORTS}

An 84-year-old male patient with dysplastic nevus syndrome (Figure 1,2) had a nodular melanoma Breslow thickness of 2 $\mathrm{mm}$ removed from the left side of the chest in 1996. Since then, he has had more than 30 new primary melanomas (3 lentigo maligna melanoma, 1 nodular melanoma, 21 superficial spreading melanomas (the thickest being $0.49 \mathrm{~mm}$ ), 9 melanomas in situ) removed up to date. The most recent melanoma was found on the palpebral conjunctiva, $3.15 \mathrm{~mm}$ thick. The patient had also had a basal cell carcinoma, SAMPUS (superficial atypical melanocytic proliferations of uncertain significance) lesion, and many
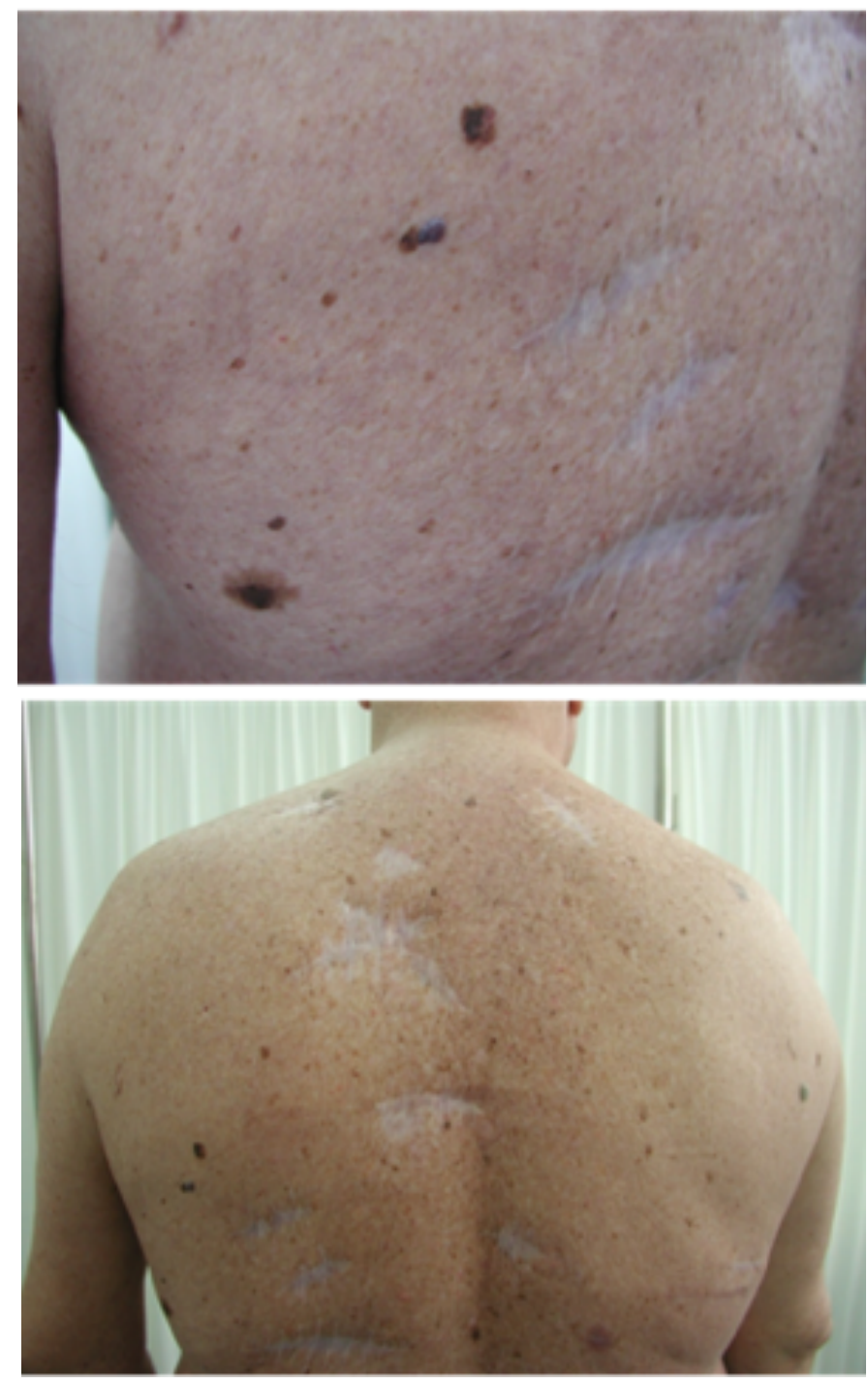

Figure 1. and Figure 2. 84-year-old male patient with dysplastic nevus syndrome and history of multiple primary melanomas

dysplastic nevi removed. Patient history revealed the patient had worked in a paint factory for many years, and had several blistering sunburns when younger. Family history is positive for melanoma, three sisters and a brother also had melanoma, while his father died of leukemia. Gene mutation analysis performed in 2011 of the p16 gene (melanoma susceptibility gene) was negative. The patient was regularly monitored every six months (since the removal of melanoma of the palpabra once more every three months) and his evaluation included dermatologic and ophthalmologic examination, LDH, S100B, basic laboratory tests, ultrasonography of regional lymph nodes, postoperative scars, and when necessary, excision of atypical lesions on the skin.

A 45-year-old male patient is regularly monitored due to melanoma excised from the chest four years ago (Cl III, Br II, Breslow thickness of $0.9 \mathrm{~mm}$ ). Given the patient has dysplastic 


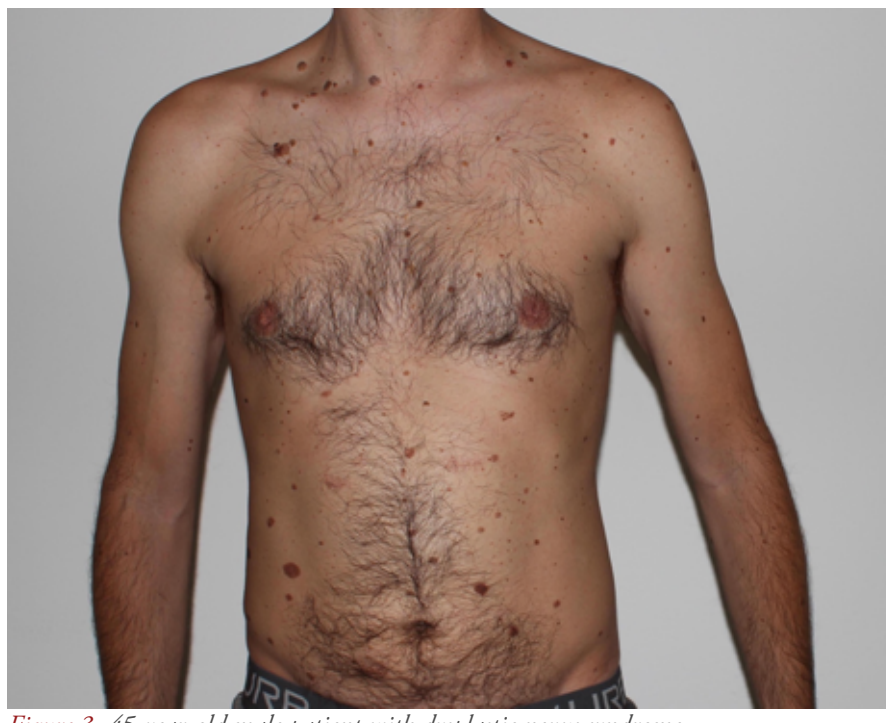

Figure 3. 45-year-old male patient with dysplastic nevus syndrome
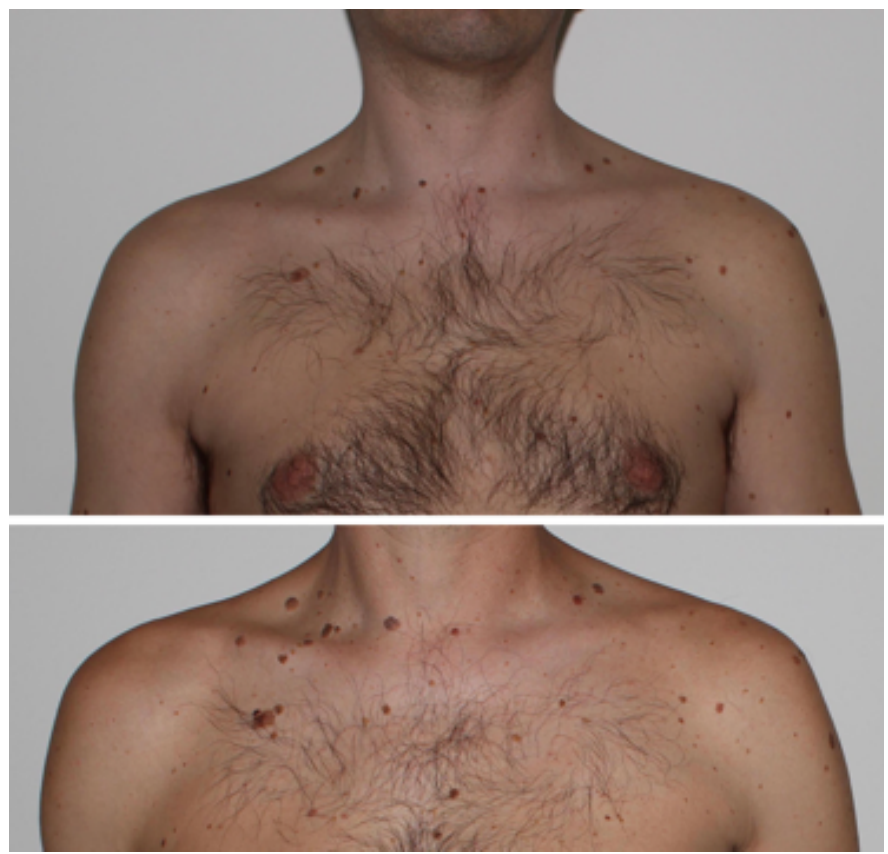

Figure 4. Four years after the first primary melanoma was removed, a newly discovered dark pigmented macula of about $5 \mathrm{~mm}$ in size was observed at the upper edge of a congenital nevus located on the skin in the right supraclavicular area during digital total-body photography follow-up

nevus syndrome (Figure 3), apart from regular dermatologic examination, the patient is also monitored with digital dermoscopy (total-body photography and sequential digital dermoscopy imaging) and, when necessary excision of atypical lesions is performed. Four years after the first primary melanoma was removed, a newly discovered dark pigmented macula of about $5 \mathrm{~mm}$ in size was observed at the upper edge of a congenital nevus located on the skin in the right supraclavicular area during digital total-body photography follow-up (Figure 4). The lesion was excised and histopathological analysis confirmed a second primary melanoma; superficial spreading melanoma (Cl II, Br I, $0.38 \mathrm{~mm}$ thick).

\section{Discussion}

Follow-up of patients with multiple primary melanomas does not differ from follow-up of patients with a single primary melanoma. Patients are monitored according to current guidelines, and thickness of the most invasive melanoma. The most significant methods of monitoring these patients are regular full-body dermatologic examinations (including scalp, genital area, oral mucous membrane and nail examination) with digital dermoscopy follow-up (total body photography and sequential digital dermoscopy imaging), as well as ophthalmologic and gynecologic examination when necessary.

Digital dermoscopy helps record the dynamic changes of pigmented skin lesions. Therefore, discrete morphological changes in existing or newly diagnosed lesions observed in digital dermoscopy, for example asymmetric growth of a nevus, may indicate development of melanoma despite the absence of other specific dermoscopic and clinical criteria for melanoma ${ }^{23}$. Salerni and colleagues carried out a meta-analysis of 14 studies (5787 patients) investigating the impact of digital dermoscopy on the monitoring of melanocytic lesions in people with increased risk for melanoma development. Results of the study showed that digital dermoscopy follow-up significantly increased the detection of early melanoma in high-risk patients, thus reducing the number of unnecessary excisions of benign lesions ${ }^{24}$.

In addition to carrying out diagnostic procedures according to guidelines, it is extremely important to educate multiple primary melanoma patients about the significance of regular skin self-examinations, use of sun-protective measures and dermatologic examination of other family members ${ }^{25,26}$.

\section{ConCLusion}

Although multiple primary melanomas are referred to as a relatively rare entity in the literature, we believe the number of patients with multiple primary melanomas is higher than previously recognized. All patients diagnosed with a primary melanoma have a high risk of developing a second or more primary melanomas, therefore regular dermatologic follow-up with a thorough examination of the skin and visible mucous membranes is essential. For individuals with a large number of atypical nevi and history of melanoma, the most effective method for early detection of other primary melanomas is digital dermoscopy follow-up - total-body photography and sequential digital dermoscopy imaging. This enables detection of melanoma at the earliest stage, prior to the development of classic dermoscopic and clinical characteristics of melanoma. 
AUTHOR CONTRIBUTIONS:

All authors listed have made a substantial, direct and intellectual contribution to the work, and approved it for publication.

\section{LITERATURE:}

1. Savoia P, Osella-Abate S, Deboli T, et al. Clinical and prognostic reports from 270 patients with multiple primary melanomas: a 34-year single-institution study. J Eur Acad Dermatol Venereol. 2012;26(7):882-8. doi: 10.1111/j.1468-3083.2011.04181.x.

2. Youlden DR, Youl PH, Soyer HP, Aitken JF, Baade PD. Distribution of subsequent primary invasive melanomas following a first primary invasive or in situ melanoma Queensland, Australia, 1982-2010. JAMA Dermatol. 2014;150(5):526-34.

3. Pack GT, Scharnagel IM, Hillyer RA. Multiple primary melanoma. Cancer. 1952;5(6):1110-5.

4. Slingluff CL Jr, Vollmer RT, Seigler HF. Multiple primary melanoma: : incidence and risk factors in 283 patients. Surgery. 1993;113(3):330-9.

5. Vecchiato A, Pasquali S, Menin C, et al. Histopathological characteristics of subsequent melanomas in patients with multiple primary melanomas. J Eur Acad Dermatol Venereol. 2014;28(1):58-64. doi: 10.1111/jdv.12055.

6. Blackwood MA, Holmes R, Synnestvedt M, et al. Multiple primary melanoma revisited. Cancer. 2002;94(8):2248-55.

7. Ferrone CR, Ben Porat L, Panageas KS, et al. Clinicopathological features of and risk factors for multiple primary melanomas. JAMA. 2005;294(13):1647-54.

8. Titus-Ernstoff L, Duray PH, Ernstoff MS, Barnhill RL, Horn PL, Kirkwood JM. Dysplastic nevi in association with multiple primary melanoma. Cancer Res. 1988;48(4):1016-8.

9. Titus-Ernstoff L, Perry AE, Spencer SK, et al. Multiple primary melanoma: 2-year results from a population-based study. Arch Dermatol. 2006;142:433-8.

10. Nosrati A, Yu WY, McGuire J, et al. Outcomes and Risk Factors in Patients with Multiple Primary Melanomas. J Invest Dermatol. 2019;139(1):195-201. doi: 10.1016/j.jid.2018.07.009.

11. Giles G, Staples M, McCredie M, Coates M. Multiple primary melanomas: an analysis of cancer registry data from Victoria and New South Wales. Melanoma Res. 1995;5(6):433-8.

12. DiFronzo LA, Wanek LA, Elashoff R, Morton DL. Increased incidence of second primary melanoma in patients with a previous cutaneous melanoma. Ann Surg Oncol. 1999;6(7):705-11.

13. Goggins WB, Tsao H. A population-based analysis of risk factors for a second primary cutaneous melanoma among melanoma survivors. Cancer. 2003;97(3):639-43.

14. van der Leest RJ, Liu L, Coebergh JW, et al. Risk of second primary in situ and invasive melanoma in a Dutch population-based cohort: 1989-2008. Br J Dermatol. 2012;167(6):1321-30. doi: 10.1111/j.13652133.2012.11123.x.
15. Bradford PT, Freedman DM, Goldstein AM, Tucker MA. Increased risk of second primary cancers after a diagnosis of melanoma. Arch Dermatol. 2010;146(3):265-72. doi: 10.1001/archdermatol.2010.2. 16. Murali R, Goumas C, Kricker A, et al. Clinicopathologic features of incident and subsequent tumors in patients with multiple primary cutaneous melanomas. Ann Surg Oncol. 2012;19(3):1024-33. doi: 10.1245/s10434-011-2058-8.

17. Uliasz A, Lebwohl M. Patient education and regular surveillance results in earlier diagnosis of second primary melanoma. Int J Dermatol. 2007;46(6):575-7.

18. Moore MM, Geller AC, Warton EM, Schwalbe J, Asgari MM. Multiple primary melanomas among 16,570 patients with melanoma diagnosed at Kaiser Permanente Northern California, 1996 to 2011. J Am Acad Dermatol. 2015;73(4):630-6. doi: 10.1016/j.jaad.2015.06.059. 19. Menzies S, Barry R, Ormond P. Multiple primary melanoma: a single centre retrospective review. Melanoma Res. 2017;27(6):638-40. doi: 10.1097/CMR.0000000000000395.

20. Doubrovsky A, Menzies SW. Enhanced survival in patients with multi-ple primary melanoma. Arch Dermatol. 2003;139(8):1013-8. 21. Pardo LM, van der Leest RJ, de Vries E, Soerjomataram I, Nijsten T, Hollestein LM. Comparing survival of patients with single or multiple primary melanoma in the Netherlands: 1994-2009. Br J Dermatol. 2017;176(2):531-3. doi: 10.1111/bjd.14846.

22. Youlden DR, Baade PD, Soyer HP. Ten-Year Survival after Multiple Invasive Melanomas Is Worse than after a Single Melanoma: a Population-Based Study. J Invest Dermatol. 2016;136(11):2270-6. doi: $10.1016 /$ j.jid.2016.03.014

23. Salerni G, Carrera C, Lovatto L, et al. Characterization of 1152 lesions excised over 10 years using total-body photography and digital dermatoscopy in the surveillance of patients at high risk for melanoma. J Am Acad Dermatol. 2012;67(5):836-45. doi: 10.1016/j. jaad.2012.01.028.

24. Salerni G, Terán T, Puig S, et al. Meta-analysis of digital dermoscopy follow-up of melanocytic skin lesions: a study on behalf of the International Dermoscopy Society. J Eur Acad Dermatol Venereol. 2013;27(7):805-14. doi: 10.1111/jdv.12032.

25. Buljan M, Tomić Sremec N, Sremec J, Tomas D, Crnaric I, Šitum M. Disease Progression in Cases of Multiple Primary Melanoma. Acta Dermatovenerol Croat. 2015;23(4):260-4.

26. Manganoni AM, Farisoglio C, Tucci G, Facchetti F, Calzavara Pinton PG. The importance of self- examination in the earliest diagnosis of multiple primary cutaneous melanomas: a report of 47 cases. J Eur Acad Dermatol Venereol. 2007;21(10):1333-6. 